DOI: 10.1515/ausp-2017-0016

\title{
The Acquisition of the Communicative Act of Greeting: Language Parallels between Hungarian and Bulgarian
}

\author{
Savelina BANOVA \\ St. Kliment Ohridski Sofia University (Sofia, Bulgaria) \\ Department of Language Learning \\ banovasavelina@yahoo.com
}

\begin{abstract}
The acquisition of linguo-cultural competence in foreign language learning has its share in the overall process of acquiring the language. In the inter-language contact situation, the speaker has to overcome not only the language but also the cultural barrier. The present paper examines the acquisition of greetings by Hungarian native speakers in the process of learning Bulgarian language, as a result of acquiring linguo-cultural competence. The question of the nation-specific aspect of the communicative act carries an important role in foreign language acquisition, undoubtedly due to the fact that it reveals language-specific features. Furthermore, the "strangeness" of the foreign language seems to be best demonstrated within the frames of a typological analysis of the two - native and foreign - languages.
\end{abstract}

Keywords: communicative grammar, socio-pragmatics language acquisition, speech act greeting

\section{Introductory lines}

One route to successful communication is language competence - this is a well-known fact. Within the large field of language acquisition and mastering of lexemes and grammar structures, there is a rather interesting aspect, namely, pragmatic competence. The interaction between native and foreign pragmatic competence in the process of various communicative acts has been attracting the attention of researchers over the past decades with an ongoing vitality. This specific aspect of eliminating the "strangeness" in the acquisition of pragmatic competence is an object of investigation in the present work as well.

We are all aware that the implementation of speech acts plays an important role in inter-language contacts. Undoubtedly, the question of the nation-specific 
structure of the communicative act is important since it shows the particular characteristics of the speech etiquette of a given language. Therefore, whenever a foreign language has been taught or learnt, the differences in the verbal means of communication of different peoples should be taken into account.

As Ilieva-Baltova (1990: 52-53) points out, the investigation of the non-equal verbal categorizations, the nation-specific structure of the act of communication, and the nation-characteristic correspondence of verbal/non-verbal components reveal the peculiarity of a given language in a pragmatic aspect - when functioning as a complex system -, which demonstrates and ensures the communicative needs of the members of a given society (see also Markkanen 1985).

The aim of the present investigation is to compare a communicative act in two different languages, as manifested in the process of language acquisition and demonstrated as pragmatic competence in written translations of Bulgarian into Hungarian. The etiquette segment of speech on which the current research focuses is the act of greeting.

\subsection{Theoretical considerations}

There have been published laborious works on greetings in both languages (among others: Tzankov 1988, Lengyel 1977, etc.). However, a cross-linguistic interpretation of this act is rather hard to find (cf. Banova 2011: 224-238). Due to restricted space, the object in mind of the present paper will not be elaborated on the literature. In turn, the attention is focused on the concrete language data and its analysis. It is worth pointing out that the preliminary observations indicate morphological and socio-pragmatic asymmetry between Bulgarian and Hungarian.

In Bulgarian, politeness is expressed with the second person plural verb form and the second person plural pronominal form Bue (orthographic difference: the polite form is spelled with a capital letter, e.g. вие vie vs. Bue Vie 'you-polite'). In contrast with Bulgarian, in Hungarian, politeness is expressed with specific pronominal forms, both in the singular and in the plural (e.g. maga, Ön 'youSg-polite', maguk, Önök 'you-Pl-polite') and both in the third person singular and the third person plural verb forms. Right from this starting point, it is expected that Hungarian will have a larger diversity of forms, and, as Lengyel (1977: 215-117) points out, there are twenty etiquette forms of greetings which are commonly used in the language. From a socio-pragmatic perspective, the opposition familiar-stranger is relevant for Bulgarian since this is one of the conditions for using the polite form, whereas for Hungarian the opposition young-old has to be taken into account as well. Furthermore, for the performing of the speech act of greeting in Hungarian, one should also consider the gender of the interlocutors, an irrelevant factor for Bulgarian. Altogether, the preference of 
the interlocutors demonstrated in the translation form they choose is determined by various conditions, characteristic of the specific communicative act. In the course of investigation, I will consider the following base factors (on further factors, cf. Levinson 2000):

- age,

- gender,

- degree of acquaintance,

- social status, and

- formal/informal situation.

\section{Language data: the experiment}

\subsection{Participants}

Seven Hungarian native speakers took part in the linguistic experiment: four male and three female subjects. All of them were students, studying Bulgarian philology at the University of Szeged, Hungary. The level of Bulgarian language knowledge was upper-intermediate to advanced. The age of the participants varied between 20 and 26 years.

\subsection{Procedure}

For the needs of the current investigation, an experiment was carried out: the subjects had to translate nine pre-selected micro-dialogues from Bulgarian into Hungarian. As the participants received the printed Bulgarian-language microdialogues, they were told that they were taking part in a language experiment, a sociolinguistic comparison of the speech act of greeting in Bulgarian and Hungarian. All students were encouraged to be maximally adequate to the greeting situations in Hungarian society while carrying out the written translations. In order to avoid misunderstandings, all micro-dialogues were verbally discussed in regards to the specific situation in which they occurred.

\subsection{Micro-dialogues: communicative frames}

The micro-dialogues were excerpted from textbooks of Bulgarian language for foreigners (Antonova et al. 1984, Petrova 1993). The selection of the microdialogues was governed by the fact that they should contain certain grammatical rules, on the one hand, and represent various communicative situations, on the other hand. All micro-dialogues are part of larger dialogues. Each participant of the experiment was given nine micro-dialogues. The sociolinguistic parameters 
of the micro-dialogues are described below, along with the indication of the specific morphological markers.

In the first dialogue, two students - strangers to each other - greet each other. Both interlocutors use the greeting Добър ден! 'good day' and a polite form, indicated by the verb form and in the formal use of 2/Pl Bue 'you-polite'.

1. Micro-dialogue in Bulgarian (source language)

- Добър ден! 'Good day!'

- Добър ден! 'Good day!'

- Вие студентка ли сте? 'Are you-polite a student-FEM?'

- Да, студентка съм. 'Yes, I'm a student-FEM'

- И аз съм студент. 'I'm a student-MASC, too.'

In the second micro-dialogue, a young interlocutor is addressing two or more elderly interlocutors. They all know each other. The informal pronominal $T u$ 'you-SG' is used, along with the Здравей 'hello' by the elderly interlocutor, and Добър ден! 'good day' by the younger one.

2. Micro-dialogue in Bulgarian (source language)

- Здравей, Асене! 'Hello, Assen-VOC!'

- Добър ден! Как сте? 'Good day! How are you?'

- Благодаря, добре сме. Ти как си? 'Thank you, we are fine. How are you-SG?

- И аз съм добре. 'I'm fine, too.'

In the third micro-dialogue, two male students greet two female students at a meeting. The informal second person plural form здравейте 'hello-PL' is used.

3. Micro-dialogue in Bulgarian (source language)

- Здравейте момичета! 'Hello-PL girls!'

- A! Каква приятна среща! Вие не познавате Яна, приятелката ми. 'Oh! What a nice meeting! You don't know Jana, my friend.

Тя следва медииина. She studies medicine.'

- Много ми е приятно, Боян. 'Nice to meet you, Boyan.'

- И на мене, Асен. 'Me too, Assen.'

In the fourth micro-dialogue, two students, who are distant acquaintances, greet each other. They use the more formal Добър ден! 'good day' and the pronominal politeness form 2/Pl Bue 'you-polite'.

4. Micro-dialogue in Bulgarian (source language)

- Добър ден! От лекиии ли идвате? 'Good day! Are you coming from lectures?'

- Да. Цяла сутрин бях в университета. 'Yes, I was at the university all morning.'

- Вие не бяхте ли на лекиии? 'Weren't you at the lectures?'

- Не, не бях. 'No, I wasn't.' 
In the fifth micro-dialogue, two friends greet each other. The used forms are the informal здравей 'hello' and здрасти 'hi'.

5. Micro-dialogue in Bulgarian (source language)

- Асене, здравей! 'Assen-VOC, hello!'

- Здрасти, Бояне! Кое беше онова момиче? 'Hi, Boyan-VOC! Who was that girl?'

- Не казвам. 'T'm not saying.'

In the sixth micro-dialogue, two acquaintances greet each other. There is no information concerning their age. Their greeting forms are Добър ден! 'good day'.

6. Micro-dialogue in Bulgarian (source language)

- Добър ден! И ти ли си на кино? 'Good day! You are also at the movies?'

- Да. Ти сам ли си? 'Yes. Are you alone?'

- Да. А mu? 'Yes. And you?'

- Аз чакам Яна. I'm waiting for Yana.'

In the seventh micro-dialogue, two students, who are strangers to each other, greet each other. The politeness is explicitly expressed in the verb form. The greeting is the pronominal politeness form 2/Pl Bue 'you-polite', used by both interlocutors.

7. Micro-dialogue in Bulgarian (source language)

- Здравейте! 'Hello.'

- Здравейте! 'Hello.'

- Как се казвате? 'What's your name?'

- Казвам се Мария. 'My name is Maria.'

- Какво следвате? 'What do you study?'

- Медииина. 'I study medicine.'

- И аз следвам медийна. 'I study medicine, too.'

In the eighth micro-dialogue, two elderly people, who are distant acquaintances, greet each other. One of the participants is a woman. Both interlocutors use the polite form, the greeting is Добър ден! 'good day'.

8. Micro-dialogue in Bulgarian (source language)

- Добър ден, г-жа Асенова! Как сте? 'Good day, Mrs Assenova! How are you?'

- Благодаря, добре съм. 'I'm fine, thank you!'

A Buе г-н Nempoв? 'And you, Mr. Petrov?'

- Горе-долу, благодаря. 'So-so, thank you.'

In the ninth micro-dialogue, two elderly people greet each other. They use the more formal Добро утро! 'good morning' and the pronominal politeness form 2/ Pl Bue 'you-polite'. 
9. Micro-dialogue in Bulgarian (source language)

- Добро утро! 'Good morning!'

- Добро утро! 'Good morning!'

- Вие ли сте г-н Марков? 'Are you Mr. Markov?'

- Не, не съм. 'No, I'm not.'

In the language data from the experimental texts, we find the following communicative situations: the interlocutors are young strangers, young distant acquaintances, young colleagues and friends, young and elderly acquaintances, young strangers, and elderly distant acquaintances.

As seen from the sociolinguistic parameters of the nine micro-dialogues, the excerpted material does not exhaust all possible communicative situations (a rather difficult task in itself, given the large variation in the socio-factors). For example, there are no examples of greeting acts between elder colleagues, between a boss and an employee, between an adult and a child, etc. Such further extension of this interesting aspect of communicative acquisition would be in the focus of another, following work.

\section{Description of the results}

The nine micro-dialogues generated 32 translation equivalents in Hungarian (cf. the Appendix). The variation was determined by the choice of a greeting form and the choice of the verb form - from the point of view of politeness/non-politeness as well. In order to juxtapose the Bulgarian-Hungarian realizations of the speech act greeting, some informants were also invited to verify the results, as they were presented in a comparative form linguistic situation by linguistic situation (i.e. following each communicative situation from the micro-dialogues). The need of informants was also provoked by the fact that there are hardly any comparative works dealing with speech act equivalents between Bulgarian and Hungarian, and some translation solutions call for further consideration.

The translation equivalents of добър ден 'good day' in the first micro-dialogue are by two forms - szia 'hi' or jó napot 'good day', among which the first form is preferred by more participants. The polite form is substituted with the informal second person singular.

(1) Bulgarian

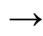

Hungarian

добър ден

jó napot

szia

In the second micro-dialogue, здравей 'hello-SG' receives three translation variants - szia, helló, szervusz, where the first two are chosen by an equal 
number of participants, three, and the last translation form by one. Furthermore, the Bulgarian greeting добър ден 'good day' is translated into Hungarian as four different greeting forms: jó napot, helló, üdv (short from üdvözöllek) and adjisten. As foreseen, the dominating choice is jó napot, used by three participants.

(2) Bulgarian здравей Hungarian helló szia szervusz добър ден jó napot helló üdvözöllek $\ddot{u} d v$ adjisten

The greeting form Здравейте момичета 'hello-PL girls' in the third microdialogue corresponds to the Hungarian sziasztok 'hi-PL' and helló (with a variant hellóka), yet the first one is preferred by the tested subjects. The formal pronominal form Bue is translated with the second person singular pronominal form in Hungarian, that is the informal form is preferred.

(3) Bulgarian

Hungarian

здравейте

sziasztok

helló (lányok)

In the fourth micro-dialogue, добър ден 'good day' receives three different translation equivalents, helló, szia 'Hi' and jó napot 'good day'. The second person singular form is used as the translation equivalent of the formal, polite second person plural form Bue 'you-PL'.

(4) Bulgarian

Hungarian

добър ден

helló

szia

jó napot

The language data from micro-dialogue five shows the translation variants of здравей, namely the Hungarian greeting forms szevasz/szia 'hi' appear, while for здрасти 'hi', szervusz and üdvözlöm are preferred.

(5) Bulgarian $\rightarrow$ здравей

Hungarian

szia

hello

szevasz 
здрасти szia

hello

szervusz

üdvözöllek

The translation solutions of the Bulgarian добър ден found in micro-dialogue six are szia, helló (again with a variation hellóka), and jó napot. Four of the participants chose to interpret the situation with szia and one with jó napot.

(6) Bulgarian $\rightarrow$ добър ден szia

helló

hellóka

jó napot

In the seventh micro-dialogue, the polite form здравейте receives predominantly the Hungarian greeting translation szia, chosen by four participants, and also helló, szevasz/üdvözöllek by one participant each. The polite form of the source text is translated into Hungarian with the informal second person singular form.

(7) Bulgarian $\rightarrow \quad$ Hungarian

здравейте szia

hello

szevasz

üdvözöllek

In the eighth micro-dialogue, the greeting Добър ден, госпожа 'Good day, Mrs' was translated with jó napot 'good day', and the word госпожа 'Mrs/Madam' was not translated at all. Only one participant used the form kezét csókolom 'I kiss your hand', along with the choice of néni 'auntie' as an equivalent of госпожа 'madam'. The polite verb form was used by all participants.

(8) Bulgarian $\rightarrow \quad$ Hungarian

добър ден, г-жа 으 ó napot kívánok

kezét csókolom, néni

In the ninth micro-dialogue, the greeting добро уmро 'good morning' is translated as jó reggelt 'good morning' without exception, and the polite verb form is used throughout the translation variants.

(9) Bulgarian $\rightarrow \quad$ Hungarian добро утро jó reggelt 


\section{Discussion and analysis of the results}

The analysis of the data from the language experiment, more exactly the translation of micro-dialogues containing greeting forms from Bulgarian into Hungarian, points out the fact that the choice of translation equivalents in Hungarian is governed rather by the sociolinguistic and the pragmatic factors defining the idiosyncrasy of the target language, and not as much by the text of the source language.

\subsection{The age factor}

In all the micro-dialogues where the context implies that the interlocutors are young people, the choice of forms are those of second person singular verbal and pronominal forms, regardless of the strangers/distant or the acquaintances/ friends factors (cf. micro-dialogues 1, 4, 5, 6, and 7). The strategy of the participants is explained by their attempt to adapt the etiquette formulas of greeting to the Hungarian language in the socio-pragmatic frame of the speech act in question. Had the participants chosen to perform an isomorphic translation, they would have probably ended up with a non-natural dialogue and a twisted communicative situation.

The translation solutions found in micro-dialogues 8 and 9 reveal a common point in the two languages: the polite forms are preferred when there are elderly and slightly acquainted people among the interlocutors. Micro-dialogue 2 shows a different picture from 8 and 9, although the communicative situation is similar. The question Как сте? 'how are you' posed by a young interlocutor to a group of elderly interlocutors has evoked only one translation equivalent with the polite form. Four participants used the second person form (i.e. the non-polite choice) and one has mistakenly used the second person singular form. One translation equivalent offers the neutral phrase Mi újság? 'what's up'.

\subsection{Translation variants}

The Bulgarian greeting forms добър ден, добро утро, здравей (здравейте), здрасти received the following Hungarian translation equivalents in the above described communicative situations: jó napot (kívánok), jó reggelt, szia (sziasztok), helló, hellóka, szervusz, szevasz, üdvözlöm (üdvözöllek), üdv, adjisten, kezét csókolom, néni (cf. the English translations above). This clearly shows and allows us to point out that the Hungarian language has a richer palette of greeting forms, both in formal and informal contexts.

Although the greeting forms добър ден and jó napot in the two compared languages are in fact isomorphs, there is no indication of preference for any 
of these translation equivalents. The results reveal that in the cases when the interlocutors are young (strangers or distant acquaintances), the majority of the participants in the experiment chose a greeting required by the particular communicative situation for the Hungarian language (e.g. micro-dialogue 1, 4, 6) rather than a 'direct' translation of the expressions in question.

Some of the participants offer the same translation equivalents for the Bulgarian forms здравей 'hello/hi' здрасти 'hi (more informal)'. The language data shows that in the perception of Hungarian speakers these two forms do not have any gradation on the formality scale. It was surprising to observe that the more familiar Bulgarian здрасти received the more formal Hungarian equivalent szervusz (5) and vice versa: the more formal здравей received the more familiar variant szevasz. We suppose that this is due to the incorrect acquisition of language material.

The results revealed by micro-dialogue 8 do not confirm the preliminary hypothesis that for Добър ден, г-жа Асенова 'good-day, Mrs Assenova' the Hungarian Kezét csókolom, Aszenova asszony 'I kiss your hand, Mrs Assenova' will be used as translation equivalent. There is only one participant who chose this particular form. However, the word asszony was substituted by the more informal néni (cf. Kezét csókolom, Aszenova néni). Further realizations in the translations were jó napot, where a female speaker was addressed as asszony 'Mrs/Madam' (cf. Jó napot (kívánok), Aszenova asszony 'good-day, Mrs. Assenova'). Informants were asked to give additional clarification regarding this specific communicative solution in the translation. One of the informants offered the explanation that if a female interlocutor holds a higher position in the hierarchy (i.e. director, boss, etc.) the neutral greeting jó napot is preferred.

Here I would like to point out another observation: the participants chose the 'full' version of the time-bound greeting jó napot kívánok only in two of the translation forms, while all other forms were jó napot. This could be a result of language transfer (given the source language form), on the one hand, or it could also be attributed to a certain tendency in the colloquial Hungarian, on the other hand. However, at this stage, it is not possible to give a unanimous answer to this issue.

\section{Conclusions}

The results obtained from the translation of etiquette formulas, i.e. greeting forms from Bulgarian to Hungarian, allow for the following conclusions:

1. There is a clear indication that the nation-specific differences in communicative situations in the two languages are taken into account and the language-specific (that is, also nation-specific) realizations are an important factor in language transfer. 
2. The thesis that politeness is governed by different requirements in the two languages is confirmed by the data. In Bulgarian, the degree of acquaintance factor is relevant, that is, it carries a crucial role, whereas in Hungarian the age factor is higher in the politeness hierarchy, while the degree of acquaintance factor is not relevant when the interlocutors are young people.

3 . The two languages demonstrate similarity in the use of polite forms when the interlocutors are elderly people and they are distant acquaintances/strangers. An expected similarity in the use of second person singular (non-polite) forms expressing informal communicative environment is also observed when the interlocutors know each other (they are friends, colleagues, etc).

4. The demonstrated differences in morphological aspect do not influence the adequacy of the translations.

\section{References}

Antonova, J, E. Kiryakova, T. Nakova. 1984. Български език. България и българите [Bulgarian Language. Bulgaria and the Bulgarians]. Sofia: Nauka i izkustvo.

Banova, Savelina. 2011. оздравите в речта на българите и унгарците [Greetings in the Language of Bulgarians and Hungarians]. In Креводът и унгрската култура [Translation and Hungarian Culture], 224-238. Sofia: Iztok-Zapad.

Ilieva-Baltova, Penka. 1990. Съвременният български език и проблемите на междуезиковите контакти [Contemporary Bulgarian Language and the Problems of Inter-language Contacts]. Sofia: Sofia University 'St. Kliment Ohridski' Publishing House.

Lengyel, Zsolt. 1977. Обращения, приветствия и прощавания в речевом этикете современной венгров [Calling, Greeting, and Parting in the Language Etiquette of Contemporary Hungarians]. In Национально-культурная специфика речевого поведения [National and Cultural Characteristics of Speech Behaviour], 193218. Moscow: Nauka.

Levinson, S. C. 2000. Presumptive Meanings: The Theory of Generalized Conversational Implicature. Cambridge, MA: MIT Press.

Markkanen, Raija. 1985. Cross-Language Studies in Pragmatics (Jyväskylä CrossLanguage Studies 11). Jyväskylä: Jyväskylä University.

Papp, Ferenc. 1985. Ф. Nan. Nаралингвистические факты, этикет и язык. [Paralinguistic Facts, Etiquette, and Language]. In Новое в зарубежой лингвистике. [News in Linguistics Abroad 15]. Moscow: Progress.

Petrova, Stefka, ed. 1993. Үчете български език [Study Bulgarian Language]. Sofia: Ivan Bogorov.

Szabó, Zoltán, ed. 2003. Semantics vs Pragmatics. Oxford: Oxford University Press. Tzankov, K. 1988. Речев етикет [Language Etiquette]. Sofia: Narodna Prosveta. 


\section{Appendix}

1.

- Добър ден

- Добър ден!

- Вие студентка ли сте

- Да студентка съм.

- И аз съм студент.

$1 a$.

- Szia!

- Szia!

- Egyetemista vagy?

- Aha

- Én is.

$1 \mathrm{~b}$.

- Jó napot (kívánok)!

- Jó napot!

- Tanulsz?

- Igen, tanulok.

- Én is.

2.

- Здравей, Асене!

- Добър ден! Как сте?

- Благодаря, добре сме. Ти как си?

- И аз съм добре.

2a.

- Helló, Aszen!

- Helló, Aszen! Hogy vagytok?

- Kösz, jól vagyok. És te?

- Én is.

$2 \mathrm{~b}$.

- Helló, Aszen!

- Adjisten! Hogy vagytok?

- Kösz, jól. Te hogy vagy?

- Én is jól vagyok. 2c.

- Helló, János!

- Üdvözöllek! Hogy vagy?

- Köszönöm, jól vagyok. És te, hogy vagy?

- Én is jól vagyok.

$2 d$.

- Szervusz, Aszen!

- Üdv! Hogy vagytok?

- Köszönöm, jól vagyunk. Te hogy vagy?

- Én is jól.

$2 \mathrm{e}$.

- Szia, Aszen!

- Jó napot! Hogy vagytok?

- Köszönöm, jól vagyok. És te, hogy vagy?

- Én is jól.

$2 f$.

- Szia, Aszen!

- Sziasztok! Hogy vagytok?

- Kösz, jól. És te, hogy vagy?

- Én is jól.

3.

- Здравейте момичета!

- А! Каква приятна среща! Вие не познавате Яна, приятелката ми.

Тя следва медицина.

- Много ми е приятно, Боян.

- И на мене, Асен.

$3 a$.

- Sziasztok, lányok!

- ÁÁ! Micsoda meglepetés. Ismered Jánát, a barátnőmet? Orvosis.

- Helló, Boján.

- Helló, Aszen. 
$3 \mathrm{~b}$.

- Helló, lányok!

- Á! Micsoda kellemes találkozás Te nem ismered Jánát, a barátnőmet.

- Szia, Boján!

- Szia, Aszen!

3c.

- Sziasztok, lányok!

- Á, micsoda találkozás! Ti még

nem ismeritek a barátnőmet, Janát.

Orvostanhallgató.

- Örvendek, Bojan.

- Én is, Aszen.

3d.

- Sziasztok, lányok!

- Áá! Milyen örvendetes találkozás!

Még nem ismeritek Janát, a

barátnőmet. Orvostanhallgató.

- Nagyon örülök, Bojan vagyok.

- Én is örvendek, Aszen vagyok.

3 e.

- Sziasztok, lányok!

- De jó, hogy találkoztunk! Még

nem ismeritek Jánát, a barátnőmet.

Orvosira jár.

- Helló, Bojan vagyok.

- Aszen.

4.

- Добър ден! Om лекции ли идвате?

- Да. Цяла сутрин бях в университета.

Вие не бяхте ли на лекции?

- Не, не бях.

4a.

- Helló! Mi újság? Óráról jössz?

- Ja. Egész délelőtt az egyetemen

voltam. Te nem voltál?
- Nem, nem voltam.

$4 \mathrm{~b}$.

- Szia! Hogy vagy? Óráról jössz?

- Igen, egész délelőtt az egyetemen

voltam. Te nem voltál órákon?

- Nem voltam.

4c.

- Jó napot! Hogy van? Óráról jön?

- Igen. Egész délelőtt az egyetemen voltam. Ön nem volt órán?

- Nem voltam.

5.

- Асене, здравей!

- Здрасти, Бояне! Кое беше онова момиче?

- Не казвам.

$5 a$.

- Aszen, helló!

- Helló! Ki volt az a lány?

- Mit tudom én.

$5 b$.

- Szia, Aszen!

- Szia, Bojan! Ki volt az a lány?

- Nem árulom el.

$5 c$.

- Helló János!

- Üdvözöllek István! Ki volt az a lány veled?

- Nem mondom meg.

$5 d$.

- Aszen, szevasz!

- Szervusz, Bojan! Ki volt az a lány?

- Nem árulom el. 
5 e.

- Szia Aszen!

- Helló, Bojan! Ki volt az a lány?

- Nem tudom.

6.

- Добър ден! И ти ли си на кино?

- Да. Ти сам ли си?

- Да. А ти?

- Аз чакам Яна.

$6 a$.

- Hellóka! Te is moziba?

- Aha! Egyedül vagy?

- Igen, és te?

- Én Jánát várom.

$6 b$.

- Helló! Te is moziba mész?

- Ja. Egyedül vagy?

- Egyedül. És te?

- Janát várom.

6c.

- Szia! Te is moziba mész?

- Igen. Egyedül vagy?

- Egyedül. És te?

- Janát várom.

$6 d$.

- Jó napot! Moziba jössz?

- Igen. Te egyedül vagy?

- Igen. És te?

- Én Janát várom.

7.

- Здравейте!

- Здравейте!

- Как се казвате?

- Казвам се Мария.

- Какво следвате?
- Медицина.

- И аз следвам медицина.

$7 a$.

- Szevasz!

- Szevasz!

- Hogy hívnak?

- Mária vagyok.

- Hova jász?

- Orvosira.

- Én is.

$7 \mathrm{~b}$.

- Helló!

- Helló!

- Hogy hívnak?

- Mariának.

- Mit tanulsz?

- Orvosis vagyok

- Én is.

7c.

- Üdvözöllek!

- Üdvözöllek!

- Hogy hívnak?

- Mária vagyok.

- Mit tanulsz?

- Orvostanhallgató vagyok.

- Én is orvosira járok.

$7 d$.

- Szia!

- Szia!

- Hogy hívnak?

- Merinek.

- Hova jász?

- Az orvosira.

- Én is. 
8.

- Добър ден, г-жа Асенова! Как сте?

- Благодаря, добре съм.

А Вие г-н Nетров?

- Горе-долу, благодаря.

8a.

- Kezeit csókolom, Aszenova néni! Hogy van?

- Köszönöm, jól. És Ön?

- Megvagyok, köszönöm.

$8 \mathrm{~b}$.

- Jó napot (kívánok), Aszenova asszony! Hogy van?

- Köszönöm, jól vagyok. És Ön?

- Szo-szo. Köszönöm.
9.

- Добро уmpo!

- Добро уmpo!

- Вие ли сте г-н Марков?

- Не, не съм.

9. a.

- Jó reggelt!

- Jó reggelt!

- Ön Markov úr?

- Nem, nem én vagyok. 